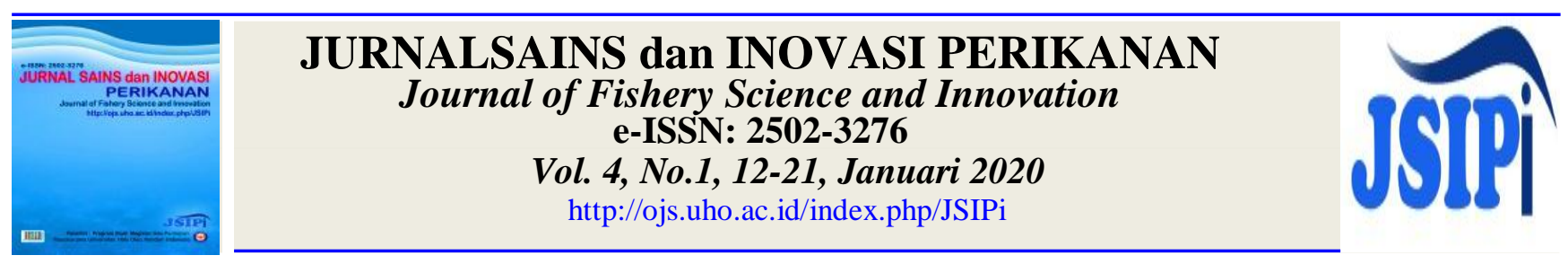

\title{
Stek Menggunakan Dua Sumber Bibit Rumput Laut (Kappaphycus alvarezii) yang Berbeda
}

\section{The Grafting Used Two Different Sources of Seaweed Seedlings (Kappaphycus alvarezii)}

\author{
Armin $^{\left.1)^{*}\right)}$, La Ode M. Aslan ${ }^{2)}$, Andi Besse Patadjai ${ }^{3)}$ \\ ${ }^{1)}$ Program Studi Ilmu Perikanan Pascasarjana Universitas Halu Oleo, Kendari, Indonesia \\ ${ }^{2)}$ Program Studi Budidaya Perairan Fak. Perikanan dan Ilmu Kelautan, Kendari, Indonesia \\ ${ }^{3)}$ Program Studi Budidaya Perairan Fak. Perikanan dan Ilmu Kelautan, Kendari, Indonesia \\ Corresponding author ${ }^{*}$ : aslaod1966@gmail.com
}

\begin{abstract}
The grafting is one method that can improve the quality of seaweed seedlings 'using two different seedlings sources. Two seed sources used were prof seedlings and tissue culture. The purpose of this study was to determine the grafting rate, daily growth rate (DGR), ratio fresh weight (FW) and dry weight (DW), carrageenan yield, viscosity, and gel strength using a combination of two different seedlings : prof (P) and tissue-cultured (TC) seedlings. Stright -slipped grafting method was employed in this study. This research was done from January-June 2019. From this study, it was found that the grafting rate was 93.33\%, ratio of FW: DW 7.07:1 For the DGR the highest average was found in the combination of P vs TC $(6.06 \pm 0.14 \%$ /day). In addition, for carrageenan yield, the highest was found from P vs TC seedlings $(58.74 \pm 2.04 \%$, viscosity $348.2 \pm 10.60 \mathrm{cps}$ and gel strength $1,066.3 \pm 77,833$ $\mathrm{g} / \mathrm{cm}^{2}$ ). In conclusion, the grafting of prof and tissue-cultured seedlings showed higher quality than those of the treatment without using different seedling sources (prof and/or tissue-culture alone)
\end{abstract}

Keywords: grafting, straight slipped, prof, tissue culture

\begin{abstract}
ABSTRAK
Metode stek merupakan salah satu metode yang dapat meningkatkan kualitas bibit rumput laut dengan menggunakan dua sumber bibit yang berbeda. Dua sumber bibit yang digunakan adalah bibit prof dan kultur jaringan. Tujuan penelitian ini adalah untuk mengetahui persentase penempelan stek, rasio berat basah : berat kering, laju pertumbuhan harian (LPH), kadar karaginan, viskositas, dan kekuatan gel dari kombinas kombinasi dua sumber bibit tersebut menggunakan metode stek lurus. Penelitian ini telah dilaksanakan di bulan Januari-Juni 2019. Rata-rata persentase penempelan mencapai 92,5\%, berat basah (BB) : berat kering (BK) 7,07:1. Semua parameter menunjukkan kombinasi nilai tertinggi diperoleh pada perlakuan antara prof dan kutur jaringan. LPH $(6,06 \%$ /hari \pm 0.14$)$, kandungan karaginan $(58,74 \% \pm 2.04)$, viskositas tertinggi $(348,2 \mathrm{cps} \pm 10,60)$ dan kekuatan gel tertinggi perlakuan $(1.066,3 \mathrm{~g} / \mathrm{cm} 2 \pm 77,833)$. Kesimpulan, hasil stek bibit prof vs kultur jaringan menunjukkan kualitas yang lebih tinggi daripada perlakuan tanpa menggunakan sumber bibit yang berbeda (prof dan / atau kultur jaringan saja)
\end{abstract}

Kata Kunci: metode stek, stek lurus, prof, kultur jaringan

DOI: http://dx.doi.org/10.33772/jspi.v4.n1.10976

\section{PENDAHULUAN}

Permasalahan utama dalam mendorong pengembangan budidaya rumput laut di Indonesia adalah kualitas rumput laut yang dihasilkan para pembudidaya di Indonesia pada umumnya masih rendah (Aslan et al., 2015; Aslan dkk., 2016). Rendahnya kualitas rumput laut pada umumnya disebabkan oleh 3 (tiga) hal, yaitu: (i) kualitas bibit yang kurang baik, (ii) waktu panen yang tidak tepat, dan (iii) proses penjemuran yang tidak memadai. Selain itu, rendahnya kualitas rumput laut juga disebabkan oleh kebiasaan para pembudidaya yang tidak tepat pada teknis pemeliharaan, cara panen, dan cara penyimpanan rumput laut kering (Aslan dkk., 2018; Aslan et al., 2018 dan Aslan et al., in press). 
Untuk mendukung pengembangan industri bibit rumput laut di Indonesia yang berkualitas diperlukan upaya pengembangan bibit unggul melalui metode kultur jaringan (Yong et al., 2014). Penelitian tentang pengadaan bibit hasil kultur jaringan pada rumput laut sudah banyak dilakukan (Yunque et al., 2011; Sulistiani, dkk., 2014). Penelitian bibit hasil kultur jaringan yang dilakukan oleh Yong et al (2014) hanya menguji kelayakan tumbuh di alam sedangkan Sulistiani et al (2014) hanya terbatas pada uji pertumbuhan dan kadar karaginan.

Penggunaan bibit rumput laut hasil kultur jaringan yang berkelanjutan dan berkualitas baik adalah solusi untuk mengatasi mengenai permasalahan kualitas rumput laut (Rama et al, 2018). Sapitri, dkk. (2016) menyatakan bahwa, rumput laut yang berasal dari bibit kultur jaringan memiliki pertumbuhan yang lebih tinggi dibandingkan dengan bibit yang bukan hasil kultur jaringan.

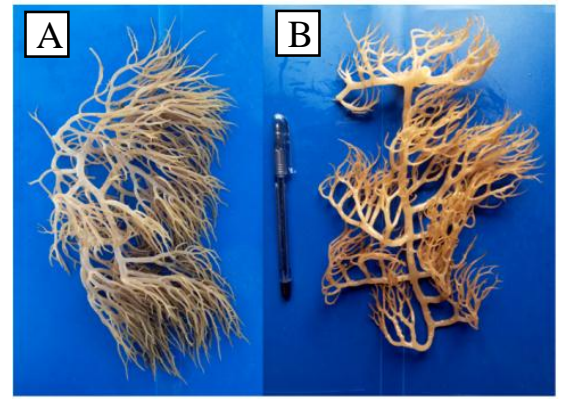

Gambar 1. Morfologi Rumput laut. A. Rumput laut prof; B. Rumput laut kuljar

Reddy, et al. (2003) juga telah menyatakan bahwa, bibit yang berasal dari hasil kultur jaringan memiliki tingkat pertumbuhan yang lebih tinggi (1.5 - 1.8 kali) dibanding bibit yang tanpa melalui proses kultur jaringan yang dibudidayakan di India. Bibit hasil kultur jaringan memiliki laju petumbuhan yang lebih tinggi dibandingkan bibit yang berasal dari alam (Yong et al., 2014).

Hasil studi oleh Aslan dan Ruslaini (2015) tentang penggunaan bibit rumput laut hasil kultur jaringan di Sultra menunjukkan bahwa bibit ini memiliki keunggulan pertumbuhan, terhadap suhu khususnya di musim kemarau.

Saat ini beberapa metode budidaya untuk mendapatkan bibit unggul telah dilakukan melalui metode seleksi massal (Fadila et al., 2016), metode stek (Sahu et al., 2011) dan kombinasi seleksi massal dan kultur jaringan (Aslan $d k k$ 2018). Bibit rumput laut yang dihasilkan dari hasil seleksi massal yang dikombinasikan metode kultur jaringan (kuljar) diistilahkan dengan "prof". Oleh karena itu, keunggulan bibit hasil kultur jaringan menggunakan metode stek hingga saat ini masih sangat minim khususnya penelitian menggunakan bibit kultur jaringan yang distek (Aslan $d k k$., 2018). Kombinasi yang akan dilakukan dalam penelitian ini adalah stek antar bibit prof vs kultur, prof vs prof dan rumput laut kuljar kontrol. Penelitian ini bertujuan untuk mengetahui persentase penempelan, laju pertumbuhan harian (LPH), rasio berat basah dan berat kering serta analisis kadar karaginan, viskositas dan kekuatan gel.

\section{METODE PENELITIAN}

Penelitian ini dilaksanakan pada bulan Januari hingga Juni 2019 (selama 6 bulan). Penelitian ini terdiri dari dua bagian yaitu penelitian lapangan dan dilanjutkan dengan analisis laboratorium.

Lokasi penelitian lapang di Desa Koepisino, Kecamatan Bonegunu, Kabupaten Buton Utara, Provinsi Sulawesi Tenggara dengan garis lintang $4^{\circ} 49^{\prime} 9.04 " \mathrm{~S}$ dan garis bujur $123^{\circ} 1^{\prime} 43.89^{\prime \prime} \mathrm{E}$. Sedangkan analisis laboratorium dilaksanakan di Laboratorium Teknik Kimia, Jurusan Teknik Kimia, Politeknik Negeri Ujung Pandang Makassar.

\section{Penyediaan Bibit Uji}

Bibit rumput laut $K$. alvarezii hasil kultur jaringan yang digunakan berasal dari bibit rumput laut yang dihasilkan dari proses kultur jaringan hasil penelitian sebelumnya yang dilakukan oleh Aslan dan Ruslaini (2015) dan rumput laut prof yang dilakukan oleh Aslan et al., (2018).

\section{Pelaksanaan Metode Stek pada Bibit}

Metode stek pada bibit unggul rumput laut yaitu kombinasi stek antar prof dan kultur. Proses stek rumput laut adalah sebagai berikut:

1. Memotong dan pisahkan pada bagian pangkal dan ujung rumput laut.

2. Memotong tallus hingga menyisakan pangkal rumput laut.

3. Memotong/mengiris lurus kedua sisi di bagian pangkal rumput laut

4. Menyatukan kedua rumput laut dengan menggunakan tali plastik es. Tali pengikat rumput laut dari plastik es yang ditarik hingga membentuk tali, tujuan menggunakan tali es agar 
rumput laut tidak mudah terlepas selama pemeliharaan.

Metode stek pada bibit unggul rumput laut menggunakan 2 (dua) kombinasi stek antar kuljar vs prof, prof vs prof. Proses stek rumput laut adalah sebagai berikut:

a. Menyatukan kedua rumput laut dengan menggunakan tali plastik es. Tali pengikat rumput laut dari plastik es yang ditarik hingga membentuk tali, tujuan menggunakan tali es agar bibit rumput laut tidak mudah luka dan tidak mudah terlepas selama pemeliharaan. Aslan $d k k$., (2018) telah melakukan uji coba awal penanaman menggunakan metode sambung samping dan sambung lurus pada bibit hasil kultur jaringan yang dikombinasikan dengan strain lokal.

b. Bibit rumput laut yang telah di stek kemudian dipelihara dan monitoring selama 2 pekan, untuk mengetahui keberhasilan bibit stek dilakukan monitoring 2 hari sekali untuk membersihkan bibit dari lumpur atau organisme pengganggu. Jumlah bibit awal yang distek masing-masing perlakuan 20 bibit.

\section{Persiapan Lokasi}

Lokasi yang digunakan memenuhi kriteriakriteria seperti bebas dari pencemaran dan ketersediaan nutrisi (Hurtado et al., 2009) serta keterlindungan dari ombak, jauh dari jalur pelayaran, dan parameter kualitas air yang baik. Lokasi penelitian adalah di perairan teluk Bonegunu, Desa Koepisino, Kecamatan Bonegunu Kabupaten Buton Utara, Provinsi Sulawesi Tenggara.

\section{Pemeliharaan Bibit Pasca Stek}

Bibit stek rumput laut dipelihara selama 10 hari. Monitoring untuk mengamati penempelan, kebersihan, dan perawatan dilakukan setiap 2 hari sekali. Bibit yang telah siap ditanam diikat pada tali ris dengan panjang $12 \mathrm{~m}$. Jumlah bibit pada masingmasing perlakuan adalah 20 bibit.

\section{Metode Penanaman}

Metode yang dipersiapkan untuk penelitian ini adalah metode long line. Sedangkan jenis bibit yaitu kultur jaringan dan bibit rumput laut prof. Setiap perlakuan diulangi 5 kali.

\section{Pemanenan Bibit Hasil Stek}

Pemanenan bibit hasil stek dilakukan setelah bibit telah menempel (umur 10 hari pemeliharaan) yaitu sebagai berikut :

1. Menyiapkan peralatan yang dibutuhkan diantaranya, perahu, timbangan digital dengan satuan terkecil $0,1 \mathrm{~g}$ dan peralatan menulis.
2. Melakukan pemanenan pada saat bibit stek telah menempel kuat

3. Memasukkan rumput laut ke dalam perahu dengan hati-hati agar rumput laut tidak patah dan dipastikan bibit tetap utuh

4. Memisahkan tiap-tiap perlakuan untuk memudahkan dalam pengambilan data

5. Memotong rumput laut stek sesuai dengan perlakuan untuk pemeliharaan lebih lanjut selama 45 hari.

\section{Prosedur Kerja Lapangan Lanjutan \\ Perbanyakan Bibit}

Tali pengikat bibit rumput laut yang digunakan adalah berbahan plastik (plastik es). Tali plastis es adalah tali yang cocok untuk mengikat setiap bibit rumput laut stek, agar rumput laut tidak terhempas akibat arus/ombak. Pemeliharaan bibit stek dilakukan selama 10 hari sampai benar-benar melempel secara sempurna kedua bagian. Setiap bentangan terdiri dari 20 rumpun bibit hasil stek. Jumlah keseluruhan bibit pada tali bentangan 120 bibit untuk masing-masing perlakuan jenis bibit. Setelah itu, rumput laut dipelihara selama 45 hari

\section{Metode Penanaman}

Metode yang dipersiapkan untuk penelitian ini adalah metode long line. Sedangkan jenis bibit yaitu kultur jaringan, bibit rumput laut prof dan bibit kuljar tanpa stek sebagai kontrol dengan 5 kali ulangan.

\section{Pemasangan bibit}

Bibit stek ditimbang, lalu diikat pada tali bentangan. Setiap bentangan terdiri dari 20 rumpun. Jumlah keseluruhan bibit pada tali bentangan 180 bibit.

\section{Pemeliharaan Organisme Uji}

Pemeliharaan dilakukan selama 45 hari. Pengontrolan organisme uji selama masa pemeliharaan dengan membersihkan kotoran pada tali ris dan rumput laut berupa lumut atau epifit yang dilakukan setiap 2 (dua) hari sekali. Penimbangan dilakukan 9 hari sekali.

\section{Pemanenan}

Pemanenan dilakukan dengan cara sebagai berikut:

- Melepas pengikat antara tali ris dengan tali utama

- Menarik tali rumput laut secara berlahan-lahan

- Mengangkut rumput laut ke dalam perahu dan memastikan rumput laut dalam keadaan utuh dan tidak patah atau rusak.

Kemudian tahap pengeringan dengan cara penjemuran menggunakan metode gantung. Penjemuran rumput laut adalah sebagai berikut: 
- Mengelompokkan rumput laut berdasarkan perlakuan masing-masing

- Menjemur rumput laut dengan metode gantung Menyesuaikan jarak ikatan rumput laut pada tiang jemuran agar tingkat kekeringan merata.

\section{Parameter yang Diamati}

Parameter yang diamati selama penelitian adalah:

1. Persentase keberhasilan penempelan

2. Laju pertumbuhan harian (LPH) untuk semua panen yang dibudidayakan selama 45 hari dihitung untuk periode pertumbuhan yang berbeda yang diadopsi oleh (Yong et al., 2013) menggunakan rumus: $\mathrm{LPH}(\%)=[(\mathrm{Wt} / \mathrm{W} 0) 1 /$ $\mathrm{t}-1] \times 100 \%$, di mana W0 adalah bobot berat awal sedangkan Wt adalah bobot berat akhir $(\mathrm{g})$ dari bibit dan $\mathrm{t}$ adalah jumlah hari pemeliharaan dan dengan standar deviasi diperoleh untuk LPH. Data dinyatakan sebagai rata-rata \pm SD untuk semua panen dari periode pertumbuhan masingmasing untuk periode penelitian.

3. Rasio berat basah terhadap berat kering (BB:BK). Setelah pembersihan rumput laut yang dipanen di laboratorium dengan menghilangkan pasir dan organisme lain yang menempel, semua rumput laut kering yang dipanen dari masingmasing sumber rumput laut ditimbang (g). Setelah dikeringkan dengan menggunakan metode gantung selama 2-3 hari, berat kering akhir (g) adalah juga diukur.

4. Analisis kandungan rumput laut yaitu kadar karaginan, viskositas dan kekuatan gel di Laboratorium Teknik Kimia, Politeknik Negeri Ujung Pandang.

\section{Analisis Data}

Analisis statistik dari semua perlakuan dianalisis oleh ANOVA. Jika analisis menunjukkan pengaruh yang signifikan, maka dilanjutkan dengan uji Tukey dengan tingkat kepercayaan $95 \%$ menggunakan perangkat lunak statistik SPSS versi 16.

\section{HASIL DAN PEMBAHASAN}

\section{Hasil}

\section{Persentase Penempelan Stek Bibit Rumput Laut}

Semua perlakuan pada umur 8 (delapan) hari pemeliharaan bibit stek sudah menempel dengan ratarata persentase penempelan mencapai $95,0 \%$ dengan kisaran persentase untuk semua perlakuan adalah 90$100 \%$ sedangkan hari ke-10 hanya $92,5 \%$ dengan kisaran untuk semua perlakuan adalah 90-95\% (Tabel $1)$.
Tabel 1. Persentase Penempelan Stek Bibit Rumput Laut

\begin{tabular}{ccccccc}
\hline $\begin{array}{c}\text { Hari } \\
\text { Monitoring }\end{array}$ & $\begin{array}{c}\text { Perlakuan } \\
\text { Stek }\end{array}$ & $\begin{array}{c}\text { Jumlah } \\
\text { Bibit yang } \\
\text { tidak } \\
\text { berhasil } \\
\text { Menempel }\end{array}$ & $\begin{array}{c}\text { Jumlah } \\
\text { Bibit } \\
\text { Akhir } \\
\text { yang } \\
\text { hidup }\end{array}$ & $\%$ & $\begin{array}{c}\text { Rata- } \\
\text { rata } \\
\text { penem } \\
\text { pelan } \\
(\%)\end{array}$ \\
\hline \multirow{2}{*}{ hari ke-8 } & PR vs KJ & 2 & 10 & 18 & 90 & 95,0 \\
& PR vs PR & 0 & 0 & 20 & 100 & \\
hari ke-10 & PR vs KJ & 2 & 10 & 18 & 90 & 92,5 \\
& PR vs PR & 1 & 5 & 19 & 95 & \\
\hline
\end{tabular}

Perlakuan prof (PR) vs prof (PR) memiliki penempelan paling cepat pada hari ke-8 pemeliharaan dengan presentasi $100 \%$, pada perlakuan kuljar prof (PR) vs prof (PR) presentase hanya mencapai 90,0\% atau terdapat 2 rumpun yang tidak berhasil menempel dari 20 jumlah rumpun yang distek.

Hasil stek di hari ke-10 pemeliharaan seluruh perlakuan telah menempel sempurna walaupun tingkat penempelannya bervariasi. prof (PR) vs prof (PR) mencapai $95 \%$ dan perlakuan kuljar (KJ) vs prof (PR) berhasil menempel mencapai $90 \%$ atau 18 bibit yang berhasil menempel dengan sempurna dari 20 bibit yang distek.

\section{Rasio Berat Basah dan Berat Kering (BB:BK)}

Rasio BB: BK menunjukkan adanya kecenderungan perbedaan yang signifikan antar perlakuan (Tukey test; $p<0,05$ ). BB : BK hasil stek lurus rata-rata mencapai 7,07: 1 dengan kisaran 7,73 : 1 - 6,38:1 (Tabel 2).

Rasio (BB:BK) tertinggi dari semua perlakuan secara berturut-turut adalah : kuljar (KJ) kontrol 6,40 : 1, prof (PR) vs kuljar (KJ) 6,90:1 dan prof (PR) vs prof (PR) 7,17. Hasil rasio (BB:BK) pada setiap perlakuan terlihat bahwa rasio (BB:BK) yang tertinggi terdapat pada perlakuan $(\mathrm{KJ})$ kontrol yaitu 6,40 : 1 dengan nilai awal BB 150,14 g dan BK $23,50 \pm 5,02 \mathrm{~g}$.

Tabel 2. Rasio Berat Basah dan Berat Kering (BB: BK) dari Rumput Laut $K$. alvarezi hasil stek lurus

\begin{tabular}{cccc}
\hline \multirow{2}{*}{ Perlakuan } & Wt & Wt & Rasio \\
\cline { 2 - 3 } & $\begin{array}{c}\text { Berat basah } \\
(\mathrm{BB}) \mathrm{g}\end{array}$ & $\begin{array}{c}\text { Berat kering } \\
(\mathrm{BK}) \mathrm{g}\end{array}$ & BB:BK \\
\hline & 1 & 2 & 3 \\
\hline PR vs KJ & 141,23 & $20,49 \pm 1,26$ & $6,90: 1^{\mathrm{b}}$ \\
PR vs PR & 141,80 & $19,77 \pm 3,24$ & $7,17: 1^{\mathrm{a}}$ \\
KJ (kontrol) & 150,14 & $23,50 \pm 5,02$ & $6,40: 1^{\text {c }}$ \\
\hline Rata-rata & $144,39 \pm 4,99$ & $21,25 \pm 1,98$ & $6,82: 1$ \\
\hline
\end{tabular}

* Notasi huruf yang tidak sama menunjukkan perberdaan yang signifikan $\mathrm{p}<0,05$

Catatan : $P R$ vs KJ (prof vs kuljar); PR vs PR (prof vs prof) dan KJ (kontrol kuljar) 
16 Armin, et al.

JURNAL SAINS dan INOVASI PERIKANAN / Journal of Fishery Science and Innovation Vol. 4, No. 1, 12-21, Januari 2020

\section{Laju Pertumbuhan Harian (LPH)}

Semua perlakuan yang tidak berpengaruh signifikan terhadap LPH rumput laut $(p>0,05)$. LPH rumput laut $k$. alvarezii hasil kultur jaringan tertinggi selama penelitian terdapat pada pemeliharaan hari ke9 dengan LPH rata-rata sebesar 9,37\%/hari dan kisaran semua perlakuan adalah 8,60-10,08\%/hari, rata-rata LPH hari ke-18 sebesar 8,64\%/hari dengan kisaran semua perlakuan adalah 8,38-8,84\%/hari, rata-rata LPH hari ke-27 sebesar 8,22\% hari dengan kisaran semua perlakuan 8,14-8,30\%/hari, rata-rata LPH hari ke-36 sebesar 6,91 dengan kisaran semua perlakuan 6,87-6,99\%/hari dan LPH pada hari ke 45 pemeliharaan dengan LPH rata-rata sebesar $6,04 \%$ /hari dengan kisaran semua perlakuan 6,026,06 (Gambar 2).

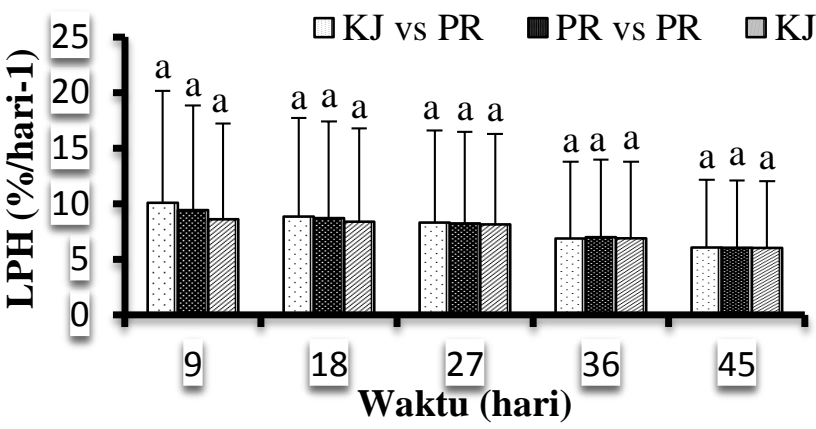

Gambar 2. LPH rumput laut hasil stek lurus semua perlakuan selama 45 hari.

\section{Kadar Karaginan}

Kadar karaginan rumput laut $K$. alvarezii ratarata $55,14 \pm 3,15 \%$ dengan kisaran 52,90 $\pm 4,03 \%$ $58,74 \pm 2,04 \%$ (Gambar 3).

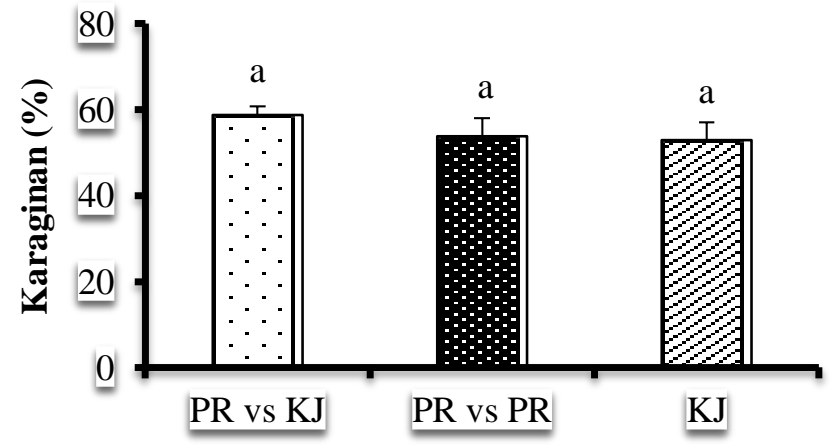

Gambar 3. Hasil karaginan rumput laut hasil stek lurus semua perlakuan selama 45 hari

Kadar karaginan tertinggi selama penelitian terdapat perlakuan prof (PR) vs kuljar (KJ) yaitu sebesar $58,74 \pm 2,04 \%$, dan terendah pada perlakuan

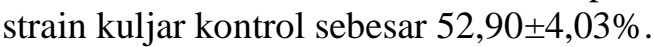

Kadar karaginan rata-rata semua pelakuan berturut-turut sebagai berikut, prof (PR) vs kuljar (KJ) 58,74 $\pm 2,04 \%$, prof (PR) vs prof (PR) $53,80 \pm 4,24 \%$ dan terendah pada perlakuan (KJ) kontrol $52,89 \pm 4,03 \%$.

Berdasarkan hasil analisis ANOVA menunjukkan bahwa semua perlakuan tidak memberikan perbedaan yang signifikan $(p>0,05)$.

\section{Viskositas}

Viskositas rumput laut $K$. alvarezii rata-rata $314,52 \pm 46,73 \mathrm{cps}$ dengan kisaran $261,16 \pm 13,73 \mathrm{cps}-$ $348,18 \pm 10,60 \mathrm{cps}$. Viskositas tertinggi terdapat pada hasil stek prof (PR) vs kuljar (KJ) yaitu $348,18 \pm 10,60$ cps sedangkan viskositas terendah pada perlakuan prof (PR) vs prof (PR) yaitu $261,16 \pm 13,73 \mathrm{cps}$ (Gambar 4)

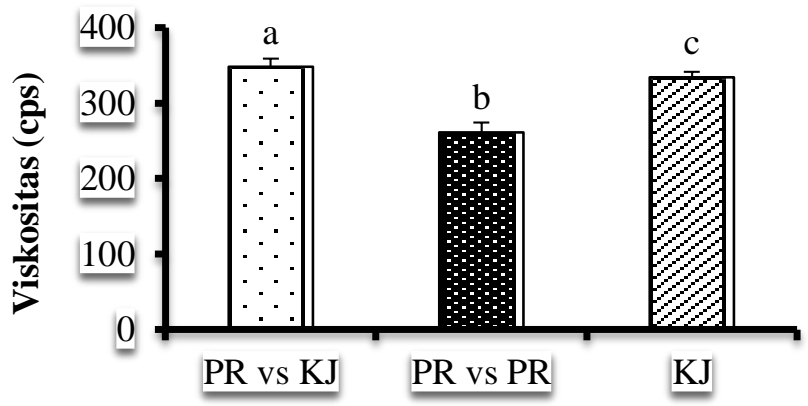

Gambar 4. Viskositas rumput laut hasil stek lurus dari semua perlakuan

Berdasarkan hasil analisis ANOVA menunjukkan bahwa semua perlakuan memberikan perbedaan yang signifikan $(p<0,05)$.

\section{Kekuatan Gel}

Kekuatan gel rumput laut $K$. alvarezii hasil stek rata-rata $999,23 \pm 58,22 \mathrm{~g} / \mathrm{cm}^{2}$ dengan kisaran $962,22 \pm 61,10 \mathrm{~g} / \mathrm{cm}^{2}-1.066,34 \pm 77,83 \mathrm{~g} / \mathrm{cm}^{2}$. Kekuatan gel tertinggi terdapat pada hasil stek prof (PR) vs kuljar (KJ) yaitu $1.066,34 \pm 77,83 \mathrm{~g} / \mathrm{cm}^{2}$ dan terendah terdapat pada rumput laut perlakuan kontrol kuljar (Lk) yaitu 962,22 $\pm 61,10 \mathrm{~g} / \mathrm{cm}^{2}$. Kekuatan gel semua pelakuan berturut-turut sebagai berikut, kuljar (KJ) vs prof (PR) $1.066,34 \pm 77,84 \mathrm{~g} / \mathrm{cm}^{2}$, prof (PR) vs prof (PR) $969,86 \pm 43,27 \mathrm{~g} / \mathrm{cm}^{2}$ dan kuljar (KJ) kontrol $962,22 \pm 39,92 \mathrm{~g} / \mathrm{cm}^{2}$ (Gambar 5) 


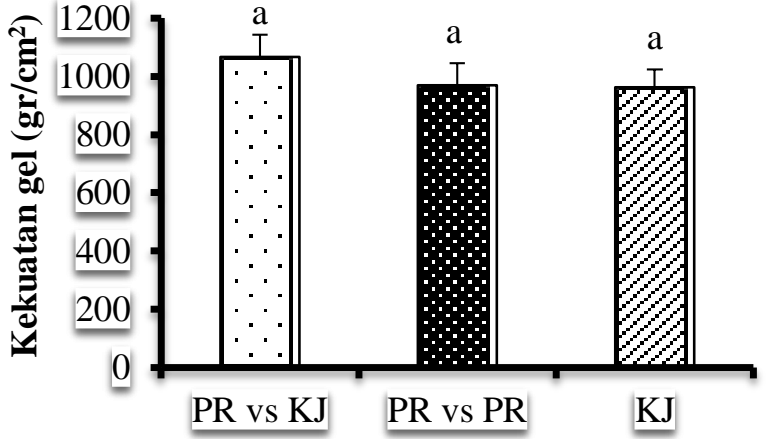

Gambar 5. Kekuatan gel rumput laut hasil stek lurus dari semua perlakuan

Berdasarkan hasil analisis ANOVA kekuatan gel semua perlakuan menunjukkan hasil yang tidak berbeda nyata.

\section{Pembahasan}

\section{Persentase Penempelan Stek}

Keberhasilan stek dari semua perlakuan rata-rata menunjukkan bahwa bibit hasil stek lurus memiliki presentasi penempelan stek yang sangat tinggi dan mampu bertahan di alam sebesar 95\% pada hari ke-8 dan $92,5 \%$ pada hari ke-10 (Tabel 1). Hal ini lebih tinggi dibanding penelitian yang dilakukan Hasriah et. al., (in press) dan Embi et. al., (in press) yang menggunakan metode stek sisipan samping. Mereka menemukan bahwa di hari ke-18 tingkat keberhasilan mencapai 43,33\%. Hasriah et. al., (in press) melakukan pengamatan 3 perlakuan $(25 \mathrm{~mm}, 30 \mathrm{~mm}$ dan $35 \mathrm{~mm}$ ) dan menemukan hasil bahwa pemeliharaan hari ke-18 persentase tertinggi pada perlakuan panjang sisipan $35 \mathrm{~mm}$ mencapai $65 \%$ sedangkan panjang sisipan $25 \mathrm{~mm}$ dan $30 \mathrm{~mm}$ masing-masing $25 \%$ dan $40 \%$. Semakin luas area sisipan maka tingkat keberhasilan semakin tinggi.

Presentasi keberhasilan penempelan dengan metode stek lurus lebih tinggi dan lebih cepat dibanding metode sisipan samping. Metode stek lurus kedua sisi irisan dapat saling menempel dengan sempurna karena posisi irisan yang lurus mudah diikat di seluruh sisi permukaan irisan rumput laut, sehingga irisan pada metode stek lurus tidak mudah lepas akibat arus dan ombak kencang serta tidak ada celah air atau partikel lumpur yang masuk pada bagian irisan.

\section{Rasio Berat Basah dan Berat Kering (BB:BK)}

Rasio (BB:BK) semua perlakuan berkisar antara 6,38: 1 - 7,73:1 (Tabel 2). Hasil berat basah dan berat kering menunjukkan adanya perbedaan signifikan antar perlakuan ( $p>0,05$; Tabel 2). Ratarata rasio (BB:BK) yang diperoleh dalam penelitian ini cenderung sebanding dengan rata-rata rasio (BB:BK) yang diperoleh dalam penelitian yang dilakukan oleh Embi et al, (2019; in press) yaitu 6,59 : 1, penelitian yang dilakukan oleh Hasriah (2019; in press) yaitu $7,42: 1$, penelitian yang dilakukan oleh Fitri et al, (2018) yaitu 8.97 : 1. penelitian yang dilakukan oleh Aeni et al, (in press) yaitu 9.69: 1 dan penelitian yang dilakukan oleh Aslan et al, (in press) yaitu $8.74: 1$.

Rasio (BB:BK) sangat dipengaruhi metode pengeringan karena melakukan pengeringan dengan metode yang baik akan menghasilkan kualitas rumput laut yang baik pula. Menurut Sulistyowati (2015), salah satu faktor yang mempengaruhi kualitas pengeringan adalah intensitas cahaya matahari. Intensitas sinar matahari yang tidak tetap dapat menyebabkan proses pengeringan tidak dapat berjalan secara maksimal akibatnya dapat terjadi pembusukan sebelum bahan menjadi kering. Solusinya ketebalan dan jarak penjemuran pada rumput laut perlu diatur untuk mempercepat proses pengeringan.

\section{Laju Pertumbuhan Harian (LPH)}

LPH rumput laut hasil stek tergolong tinggi yakni berkisar antara 6,02-6,06\%/hari. Bibit hasil stek merupakan bibit yang diperoleh dari kombinasi antara bibit prof vs kuljar, prof vs prof dan kuljar kontrol. Bibit rumput laut hasil kultur jaringan dan prof berasal dari isolasi jaringan sehingga pertumbuhan somatik terjadi lebih cepat. Sapitri $d k k$. (2016), mengatakan bahwa bibit hasil kultur jaringan merupakan bibit yang memiliki sifat unggul yang sama seperti tanaman induknya dan lebih lama terserang hama dan penyakit, berbeda dengan bibit yang bukan dari hasil kultur jaringan yang sudah digunakan sebagai bibit dari siklus pertumbuhan sebelumnya, pertumbuhan menjadi menurun dan juga tidak tahan terhadap serangan hama dan penyakit yang ada di alam.

LPH hasil stek lurus dan kontrol tidak memberikan berbedaan yang signifikan karena disebabkan rumput laut prof dan kultur jaringan merupakan bibit unggul yang sudah diuji keunggulannya di beberapa tempat diantaranya di perairan Bungin Permai oleh Aslan dkk., (2014); Aslan dkk., (2016), dan Aeni et al, (in press), Febrianti et al, (2019) di perairan Marobo kabupaten Muna. Mereka menyatakan bahwa rumput laut hasil 
18 Armin, et al.

JURNAL SAINS dan INOVASI PERIKANAN / Journal of Fishery Science and Innovation Vol. 4, No. 1, 12-21, Januari 2020

kultur jaringan dan rumput laut prof memiliki tingkat adaptasi yang tinggi dibandingkan dengan rumput laut lokal.

LPH dari penelitian ini hampir sama dengan LPH hasil stek yang diperoleh Sahu, et al. (2011), dimana LPH tertinggi $8,19 \%$ /hari dan terendah $6,10 \%$ /hari, namun lebih tinggi dibanding yang diperoleh Hasriah et. al., (2019;in pess) dimana LPH tertinggi $3,49 \%$ /hari dan terendah 3,33\%/hari.

Bibit hasil stek mengalami pertumbuhan yang cepat pada awal pemeliharaan dan cenderung menurun sampai pada umur 45 hari pemeliharaan. Hal ini senada dengan pernyataan Legit (2014), bahwa LPH rumput laut cenderung menurun seiring dengan lamanya masa pemeliharaan. Hal ini diduga karena pada awal pemeliharaan thalus yang digunakan masih muda sehingga pertumbuhan thalus berlangsung cepat. Selain itu, menurut Rasjid $d k k$. (2000), bahwa pertambahan dan pembesaran sel sudah sampai pada batas tertinggi pada kondisi optimumnya. Penambahan masa pemeliharaan akan menyebabkan terjadinya persaingan antar thallus dalam hal kebutuhan cahaya matahari, zat hara dan ruang gerak sehingga berdampak pada turunnya laju pertumbuhan dalam budidaya.

\section{Kadar Karaginan}

Hasil analisis kadar karaginan rumput laut hasil stek lurus tidak berbeda nyata pada masing-masing perlakuan. Kadar karaginan yang dihasilkan dalam penelitian ini di atas yang ditetapkan secara internasional (minimal 27\%) (Periyasamy et al., 2015) termasuk pernyatan Syahputra (2005) bahwa standar karaginan yang baik yaitu $40 \%$. Hal ini disebabkan karena rumput laut dipanen setelah berumur sekitar 45 hari yang merupakan waktu optimal pemanenan rumput laut (Periyasamy et al., 2018).

Tingginya kadar karaginan menggunakan stek lurus diduga karena rumput laut menggunakan metode ini mampu menyerap nutrient lebih banyak dan memiliki toleransi salinitas yang tinggi dibanding dengan rumput laut yang tidak distek. Hal ini sejalan dengan penelitian menggunakan tanaman labu Curubita maxima vs Curubita moschata (Usanmaz and Abak, 2019; Ceylan et. al. 2018). Dari penelitian ini ditemukan bahwa tanaman yang distek memiliki kemampuan menyerap unsur hara (nutrient) yang lebih tinggi dibanding dengan tanaman yang tidak distek. Untuk membuktikan dengan kemampuan penyerapan nutrien akibat perlakuan stek lurus, maka perlu penelitian lebih lanjut.

\section{Viskositas}

Viskositas dari penelitian sangat tinggi sebesar $348,18 \pm 10,60$ cps pada perlakuan prof vs kuljar dan terendah pada perlakuan prof vs prof $(261,16 \pm 13,73$ cps). Vikositas dari penelitian ini jauh lebih tinggi vikositas hasil stek yang diperoleh Sahu, et al. (2011), dimana viskositas berkisar 45 cps -53 cps. Semakin tinggi nilai viskositas maka semakin kental larutan karaginan sehingga karaginan yang diperoleh semakin baik. Viskositas penelitian ini telah memenuhi standar FAO (2007) karena di atas $50 \mathrm{cP}$.

\section{Kekuatan gel}

Kekuatan gel (gel strength) dinyatakan dalam satuan $\mathrm{g} / \mathrm{cm}^{2}$. Kekuatan gel yang dihasilkan semua perlakuan ekstraksi sangat tinggi dan jauh lebih tinggi jika dibandingkan dengan standar mutu kekuatan gel $\left(685,50 \mathrm{~g} / \mathrm{cm}^{2}\right)$ yaitu berkisar 962,22 $\mathrm{g} / \mathrm{cm}^{2}$ pada perlakuan kuljar kontrol dan tertinggi $1066,34 \pm 77,83 \mathrm{~g} / \mathrm{cm}^{2}$ pada perlakuan hasil stek prof vs kuljar. Kekuatan gel dari penelitian ini lebih tinggi dengan kekuatan gel hasil stek yang diperoleh Sahu, et al. (2011), dimana kekuatan gel berkisar 270 \pm 20 $\mathrm{g} / \mathrm{cm} 2-690 \pm 25 \mathrm{~g} / \mathrm{cm}^{2}$.

Kekuatan gel dari karaginan sangat dipengaruhi oleh konsentrasi $\mathrm{KOH}, \mathrm{pH}$, suhu dan waktu ekstraksi. Hal lain yang menyebabkan tingginya kekuatan gel pada karaginan komersial diduga karena kondisi bahan baku, umur panen, metode ekstraksi dan bahan pengekstrak (Wulandari, 2010) hal ini juga sejalan dengan pernyataan Yasita dan Rachmawati (2010) bahwa Kekuatan gel dan karaginan sangat dipengaruhi oleh konsentrasi alkali, suhu, dan waktu ekstraksi.

\section{KESIMPULAN}

Metode stek lurus rumput laut menggunakan kombinasi bibit rumput laut prof dan bibit hasil kultur jaringan cenderung tidak memberikan perbedaan yang signifikan baik itu rasio berat basah dan berat kering, karaginan, dan kekuatan gel. Tingkat keberhasilan persentase penempelan mencapai $93,75 \%$ dan hanya membutuhkan 8-10 hari; rata-rata berat basah : berat kering berkisar 7,03:1-6,38:1, LPH berkisar 6,02-6,06\%/hari; kadar karaginan tertinggi terdapat pada stek prof (PR) vs kuljar (KJ) $(58,74 \pm 2,04 \%)$; viskositas tertinggi terdapat pada perlakuan prof vs kuljar $(348,18 \pm 10,60$ 
cps); kekuatan gel tertinggi terdapat pada stek prof (PR) vs kuljar KJ) $\left(1.066,34 \pm 77,83 \mathrm{~g} / \mathrm{cm}^{2}\right)$

Ucapan Terima Kasih: Para penulis, L O M A dan ABP menyampaikan terimakasih kepada Kementerian Riset, Teknologi dan Pendidikan Tinggi (Kemenristek-Dikti) skim Penelitian Pengembangan SK DIRJEN RISBANG No.7/E/KPT/2019 dan KONTRAK NO. 058/SP2H/LT/DRPM/2019 yang telah membiayai penelitian ini serta para petani rumput laut di Desa Koepisino, Kecamatan Bonegunu, Kabupaten Buton Utara yang telah membantu selama proses penelitian di lapangan.

\section{DAFTAR PUSTAKA}

Aeni, O.N., Aslan L.O.M., Iba, W., Patadjai, A. B., Rahim, M. and Balubi, M. in press. Effect of Different Seedling Sources on Growth and Carrageenan Yield of Seaweed Kappaphycus alvarezii Cultivated in Marobo Waters, Muna Regency, Southeast (SE) Sulawesi, Indonesia. . IOP Conf. Series: Earth and Environmental Science.

Aslan L.O.M., Iba, W., Patadjai, A. B., Rahim, M. Febriyanti F., Hafid H., and Armin A. in press. Effect of Different Initial Weighton Growth and Carrageenan Yield of Kappaphycus alvarezii using Seedlings Produced from Mass Selection Combined with Tissue-Cultured Method. IOP Conf. Series: Earth and Environmental Science.

Aslan, L.O.M., Hasriah, R.,Embi, A.L. Ansa A., Iba, W., Patadjai, A.B., Rahim, M., Armin. In press. A Preliminary Study on the Grafting of the Seaweed Kappaphycus alvarezii in SESulawesi, Indonesia. Aquaculture Research.

Aslan L O M, Hafid H, Supendy R, Taridala S A A, Sifatu W O, Sailan Z and Niampe, L 2018 Income of Seaweed Farming Households: A Case Study From Lemo of Indonesia. IOP Conf. Series: Earth and Environmental Science 175012221

Aslan, L.O.M., Patadjai, A.B., Iba, W., Rahim, M. 2018. Pengembangan Kawasan Desa Rumput Laut Kappaphycus Alvarezii Hasil Kultur Jaringan Dalam Mendukung Peningkatan Pendapatan Masyarakat Pesisir Di Sulawesi Tenggara. Laporan Penelitian PUSNAS. UHO. Kendari. 149 Hal.
Aslan, L.O.M., Ruslaini. Iba, W., Armin., Sitti. 2016. Seaweed, Kappaphycus alvarezii, Culture Using Micropropagated Seedlings. Practical Guide of Seaweed Cultivation No.1 Faculty of Fisheries and Marine Science (FFMS) University of Halu Oleo (UHO). Accessed on August 82017.

Aslan L O M, Iba W, Bolu L R, Ingram B A, Gooley G J and Silva S S D 2015 Mariculture in SE Sulawesi Indonesia: Culture Practices and The Socioeconomic Aspects of The Major Commodities Ocean \& Coastal Management $11644-57$.

Aslan, L.O.M., Ruslaini. 2015. Pengembangan Bibit Unggul Rumput Laut Kappahycus alvarezii hasil kultur Jaringan dalam Mendukung Peningkatan Produksi Perikanan Nasional di Sultra. UHO. 54 hal.

Aslan L.O.M., Yusnaini, Legit, D. 2014. Pengaruh Jarak Tanam Terhadap Pertumbuhan dan Kadar Karaginan Rumput Laut (Kappaphycus alvarezii) Strain Coklat Menggunakan Bibit Hasil Kultur Jaringan dengan Metode Long Line. Di Bungin Permai, Kabupaten Konsel. UH0. 49 Hal.

Ceylan, S., Alan, O., Elmaci, O. L. 2018. Effects of Grafting on Nutrient Element Content and Yield in Watermelon. Ege Univ. Ziraat. Derg., 55 (1): 67-74

Dinas Kelautan dan Perikanan (DKP) Prov. Sultra. 2015. Laporan Tahunan Statistik Perikanan Budidaya Tahun 2013. Prov. Sultra. Kendari. 36 hal.

Ditjen Perikanan Budidaya, KKP, 2016. Target Produksi Rumput Laut.Jakarta

Embi, A. L., Aslan, L.O.M., Iba, W. in press. The Effect of Diffrent Inserted Thalli Weight Using Side Slice Cuttings Method Using Tissue Culture and Local, Seddlings on The Growth of the Read Seaweed (Kappahycus alvarezii). Earth and Environmental Science.

Fadilah, S., Alimuddin, Pong-Masak P.R., Santoso, J., Parenrengi, A., 2106. Growth, Morphology and Growth Related Hormone Level in Kappaphycus alvarezii Produced by Mass Selection in Gorontalo Waters, Indonesia, HAYATI J Biosci, http://dx.doi.org/10.1016/j.hjb.2015.09.004

Febriyanti, F., Aslan, L.O.M., Iba, W., Patadjai, A.B., Nurdin, A.R. 2019. Effect Of Various Planting Distances on Growth and Carrageenan Yield 
20 Armin, et al

JURNAL SAINS dan INOVASI PERIKANAN / Journal of Fishery Science and Innovation Vol. 4, No. 1, 12-21, Januari 2020

Of Kappaphycus Alvarezii (Doty) Using Seedlings Produced From Mass Selection Combined With Tissue Cultured Method. Earth and Environmental Science.

Food and Agriculture Organization (FAO). (2007). Carrageenan. Prepared at the 68th JECFA \& Published in FAO JECFA Monographs 4. $1-6$

Hasriah, R., Aslan, L.O.M., Iba, W. in press. The Effect of Diffrent Inserted Thalli Length Side Slice Cuttings Method Using Tissue Culture and Local, Seddlings on The Growth of Seaweed (Kappaphycus alvarezii) at Sasara Coastal Waters, Kulisusu Bay, Buton Utara, SE Sulawesi, Indonesia. Earth and Environmental Science.

Hurtado, A.Q., Yunque, D.A., Tibubos, K., Critchley, A.T. 2009. Use of Acadian Marine Plant Extract Powder from Ascophyllum nodosum in Tissue Culture of Kappaphycus varieties. J Appl Phycol DOI 10.1007/s10811-008-9395-4

Legit, D. 2014. Pengaruh Jarak Tanam Terhadap Pertumbuhan dan Kadar Karaginan Rumput Laut (Kappaphycus alvarezii) Strain Coklat Menggunakan Bibit Hasil Kultur Jaringan dengan Metode Long Line. Skripsi. Universitas Halu Oleo. Kendari. 125 hal.

Periyasamy, C., Subba Rao, P.V., Anantharaman, P. 2018. Harvest Optimization to Assess Sustainable Growth and Carrageenan Yield of Cultivated Kappaphycus alvarezii Doty in Indian waters. J. Appl. Phycol. Doi 10.1007/s10811-018-1562-7.

Periyasamy, C.,Subba Rao, P.V., Anantharaman. 2015. Spatial and Temporal Variation in Carrageenan Yield and Gel Strength of Cultivated Kappaphycus alvarezii (Doty) Doty in Relation to Environmental Parameters in Palk Bay Waters, Tamil Nadu, Southest Coast of India. J. Appl. Phycol. Doi 10.1007/s10811015-0536-2.

Rama, Aslan LOM, Iba W, Rahman A, Armin, Yusnaeni. (2018). Seaweed Cultivation of Micropropagated Seaweed Kappaphycus alvarezii) in Bungin Permai Coastal Waters, Tinanggea Sub District, South Konawe Regency, South East Sulawesi. IOP Conf. Series: Earth and Environmental Science 175 012219 doi :10.1088/1755-1315/175/1/012219

Rasjid F., M. Firdaus S., Pudu, Dahya, Idris, Herman, Subandi., 2000. Budidaya Rumput Laut (Eucheuma cottonii) dengan Sistem Rakit Cara
Tanam Legowo 6. Balai Pengkajian Teknologi Pertanian. Badan Penelitian dan Pengembangan Pertanian. Departemen Pertanian. Kendari.

Reddy, C.R.K., Raja, K.K.G., Siddhanta, A.K., Tewari, A. 2003. In Vitro Somatic Embryogenesis and Regeneration of Somatic Embryos from Pigmented Callus of Kappaphycus alvarezii (Doty) Doty (Rhodophyta, Gigartinales). J. Phycol. 39 : 610 $-616$.

Sahu, N., Meena, R., Ganesan, M. 2011. Effect of grafting on the properties of kappa-carrageenan of the red seaweed Kappaphycus alvarezii (Doty) Doty ex Silva. Carbohydrate Polymers 84 (2011) 584-592.

Sapitri, A. R., Cokrowati, N., Rusman. 2016. Pertumbuhan Rumput Laut Kappaphycus alvarezii Hasil Kultur Jaringan pada Jarak Tanam yang Berbeda. Depik. 5(1): 1-7.

Sulistiani E, Yani SA. 2014. Kultur Jaringan Rumput Laut Kotoni (Kappaphycus alvarezii). SEAMEO BIOTROP. Bogor (ID).

Sulistyowati, E. 2015. Pengaruh Umur Panen dan Metode Penjemuran terhadap Mutu Fisik Rumput Laut Eucheuma cottonii. Tesis. Institut Pertanian Bogor. Bogor. 55 hal.

Syahputra, Y. 2005. Pertumbuhan dan Kandungan Karaginan Budidya Rumput Laut Euchema cottonii pada kondisi lingkungan yang berbeda dan perlakuan jarak tanam di Teluk Lhok Seudu. Tesis (tidak dipublikasikan). Program Pascasarjana, Institut Pertanian Bogor. Bogor. 102 hal.

Usanmaz, S., Abak, K. 2019. Plant Growth and Yield of Cucumber plant Grafted on Different Commercial and Local Rootstocks Grown Under Salinity Stress. Saudi Journal of Bilogical Scineces. 26:1134-1139

Yunque, D.A.T., Tibubos, K.R., Hurtado, A.Q., Critchley, AT (2011). Optimatization of Culture Conditions for Tissue Culture Production of Young Plantlets of Carrageenonphyte Kappaphycus alvarezii. J. Appl. Phycol. 23:433-438

Wulandari R. 2010. Pembuatan karaginan dari rumput laut Eucheuma cottoni dengan dua metode. Laporam Tugas Akhir. Surakarta: Universitas Sebelas Maret.48 hal.

Yasita D dan Rachmawati ID. 2010.Optimasi Proses Ekstruksi pada Pembuatan Karaginan dari 
Vol. 4, No. 1. 12-21, Januari 2020

Rumput Laut Eucheuma cottoni Untuk Mencapai Food Grade. Jurusan Teknik Kimia, Fakultas Teknik, Universitas Diponegoro.Semarang.

Yong, W. T. L., Chin, J. Y. Y., Yasir, S. 2014. Evaluation of Growth Rate and Semi-refined Carrageenan Properties of Tissue-cultured Kappaphycus alvarezii (Rhodophyta, Gigartinales). Phycological Research: 62 : 316-321.

Yong, Y.S., Yong, W.T.L., Thien, V.Y., Ng, S.N., Anton. 2013. Analysis of Formulae for Determination of Seaweed Growth Rate. J. Appl. Phycol 25:1831-1824. 